УДК 351.746 .3

DOI https://doi.org/10.32849/2663-5313/2020.9.23

\title{
Яна Ковальчук,
}

ад'юнкт кафедри публічного управління та адміністрування

Національної академії внутрішніх справ

\section{ПРИНЦИПИ ІНФОРМАЦИЙНО-АНАЛІТИЧНОГО ЗАБЕЗПЕЧЕННЯ ДІЯЛЬНОСТІ ОРГАНІВ НАЦІОНАЛЬНОЇ ПОЛІЦЇ̈ УКРАЇНИ}

Метою статті є аналіз сучасної системи принципів інформаційно-аналітичного забезпечення діяльності органів Начіональної поліиії України, а також формулювання пропозицій щодо вдосконалення окремих напрямів у зазначеній сфері. У статті розглядаються проблемні питання визначення Системи приниипів інформачійно-аналітичного забезпечення діяльності органів Начіональної поліиіі України. Розглянуто загальні принципи адміністративного права, що закріплені в Конституиіі Украйни, конкретизуються і розвиваються в законодавчих та інших нормативно-правових актах. Крім того, досліджено спечіальногалузеві приниипи, взаємопов'язані з принципами публічного адміністрування, які в нормах адміністративного права постають у зміненому вигляді, набуваючи форми конкретних загальнообов'язкових вимог. Права і свободи людини і громадянина не можуть бути обмежені з мотивів, пов'язаних з використанням різних способів обробки персональних даних або позначенням приналежності персональних даних, що містяться в державних або інших інформаиійних системах персональних даних, конкретного суб'єкта персональних даних. Не допускається використання таких, що ображають почуття громадян, або таких, що принижують людську гідність, способів позначення приналежності персональних даних, що містяться в інформачійних системах персональних даних, конкретного суб'єкта персональних даних. Виділено групу спещіальних принципів інформаційно-аналітичного забезпечення діяльності органів Начіональної поліції України, які виступають основою для організації аналітичної роботи. Визначено, що принципи інформачійноаналітичного забезпечення діяльності органів Начіональної полічії України можливо класифікувати на такі види: загальноправові, галузеві та спеиіальні. До першої групи віднесено сукупність загальних приниипів, що притаманні усій системі публічного управління. До другої - сукупність принципів, які випливають зі змісту галузевих нормативно-правових актів, які визначають порядок роботи з інформачією та засади аналітичної роботи. До третьої - спеціальні приниипи, що обумовлюють порядок організачіӥ інформачійно-аналітичного забезпечення діяльності органів полічії.

Ключові слова: аналітичне забезпечення, органи поліції, система принципів, правове регулювання, публічне управління.

Постановка проблеми. Наявна в Україні система інформаційно-аналітичного забезпечення діяльності органів державної влади та управління вимагає системного підходу вчастиніметодологічногосупроводутаправового регулювання. Регламентація зазначених відносин необхідна для здійснення єдиної, скоординованої державної політики у зазначеній сфері, спрямованої на підвищення ефективності прийнятих політичних рішень.

Аналіз організації інформаційно-аналітичної діяльності в органах державної влади та управління, а також зміст нормативно-правової бази, що регулює зазначені питання, свідчить про існування відмінностей у характері й обсягах наповнення нормативно-правової бази, в підходах до визначення основних понять та організації діяльності. Правова регламентація відносин у зазначеній сфері грунтується на підходах, сформульованих без урахування практичної діяльності, що зумовлює виникнення проблем під час розробки, прийняття та реалізації правових норм, що регулюють відносини в цій сфері.

Удосконалення інформаційно-аналітичного забезпечення та нормативно-правової бази, що регулює відносини в цій сфері, передбачає розробку понятійно-категоріального апарату, який застосовується для правового регулювання зазначеної сфери; формування уніфікованої методології здійснення інформаційно-аналітичної діяльності; закріплення основних напрямів і вдосконалення правового регулювання інформаційно-аналітичної діяльності в рамках цілісної ієрархічної системи нормативно-правових актів.

Визначення та закріплення принципів інформаційно-аналітичного забезпечення дозволять створити на державному рівні 
ефективну систему інформаційно-аналітичного забезпечення, сформувати і закріпити єдині підходи до системи та змісту нормативно-правових актів, що регулюють відносини у сфері інформаційно-аналітичної діяльності, а також створити необхідні умови, спрямовані на підвищення ефективності управління суспільно-політичними процесами в суспільстві.

Принципи, які $€$ характерними для адміністративного права в цілому, можуть служити орієнтиром у здійсненні аналізу принципів правового регулювання інформаційно-аналітичної діяльності органів Національної поліції України, проте не можуть підкреслити всіх особливостей, властивих такій діяльності.

Стан дослідження проблеми. Вченими досить детально досліджувались питання принципів адміністративно-правового регулювання. Зазначені питання розкриваються у роботах таких вчених, як В. Б. Аверьянов, А. І. Берлач, Ю. П. Битяк, В. К. Колпаков, О. В. Кузьменко, В. А. Ліпкан, М. В. Лошицький, Р. А. Калюжний тощо. Окремі питання адміністративно-правового регулювання у різних спеціалізованих сферах також стали об'єктом уваги дослідників, наприклад: Д. М. Павлов досліджував принципи адміністративно-правового регулювання природно-техногенної безпеки та цивільного захисту [1], К. Б. Драмаренко розглядав принципи адміністративно-правового регулювання діяльності політичних партій в Україні [2], А. I. Шинкарук розкрив особливості принципів адміністративно-правового регулювання діяльності нотаріусів у сфері державної реєстрації [3]. Проте система принципів інформаційно-аналітичного забезпечення діяльності органів Національної поліції України у сучасній адміністративно-правовій науці не досліджена на достатньому рівні, що й зумовлює мету даної статті.

Метою статті $€$ аналіз наявної системи принципів інформаційно-аналітичного забезпечення діяльності органів Національної поліції України, а також формулювання пропозицій щодо удосконалення окремих напрямів у зазначеній сфері.

Виклад основного матеріалу. Якщо розглядати систему принципів інформаційно-аналітичного забезпечення діяльності органів Національної поліції України, то потрібно зазначити, що у науці адміністративного права принципи розділяють на загальні та спеціальногалузеві. Так, до загальних принципів відносять ті, які мають фундаментальне значення для всієї галузі адміністративного права. Вони виявляються і деталізуються в галузевих принципах адміністративного права, які у свою чергу поділяються на основні принципи та принципи формування й функціонування його окремих інститутів (наприклад, принципи державної служби, принципи адміністративної відповідальності, принципи адміністративної процедури тощо) [4].

Загалом, загальні принципи адміністративного права закріплені в Конституції України, конкретизуються і розвиваються в законодавчих та інших нормативно-правових актах, до яких належать такі, як: 1) принцип пріоритету прав та свобод людини і громадянина; 2) принцип верховенства права; 3) принцип законності; 4) принцип рівності громадян перед законом; 5) принцип демократизму правотворчості й реалізації права; 6) принцип взаємної відповідальності держави і людини; 7) принцип гуманізму й справедливості у взаємовідносинах між державою та людиною [5].

Спеціальногалузеві принципи взаємопов'язані 3 принципами публічного адміністрування, які в нормах адміністративного права постають у зміненому вигляді, набуваючи форми конкретних загальнообов'язкових вимог [6, с. 73$]$.

Наприклад, у Законі України «Про інформацію» встановлюються основні принципи інформаційних відносин, до яких належать: гарантованість права на інформацію; відкритість, доступність інформації, свобода обміну інформацією; достовірність і повнота інформації; свобода вираження поглядів і переконань; правомірність одержання, використання, поширення, зберігання та захисту інформації; захищеність особи від втручання в її особисте та сімейне життя [7]. А Законом України «Про доступ до публічної інформації» встановлюються принципи: прозорості та відкритості діяльності суб'єктів владних повноважень; вільного отримання, поширення та будь-якого іншого використання інформації, що була надана або оприлюднена відповідно до цього Закону, крім обмежень, встановлених законом; рівноправності, незалежно від ознак раси, політичних, релігійних та інших переконань, статі, етнічного та соціального походження, майнового стану, місця проживання, мовних або інших ознак [8].

Гарантії у сфері надання інформації встановлено чинним законодавством України. У рамках діяльності органів державної влади та місцевого самоврядування, а також підвідомчих їм організацій відповідні суб'єкти створюють відкриті для кожного інформаційні ресурси з питань своєї компетенції. 
Слід також зазначити, що в межах своїх повноважень, встановлених законом, вони здійснюють масове інформаційне забезпечення користувачів 3 питань прав, свобод і обов'язків громадян, їхньої безпеки та інших питань, що становлять суспільний інтерес. Відмова в доступі до публічних інформаційних ресурсів може бути оскаржена до суду.

Метою існування таких інформаційних систем, що використовуються для державних потреб, є реалізація повноважень державних органів і забезпечення обміну інформацією між цими органами, а також інші встановлені законодавством цілі.

Інформація, що міститься в державних інформаційних системах, а також інші наявні в розпорядженні державних органів відомості та документи, є державними інформаційними ресурсами. Інформація, що міститься в державних інформаційних системах, є офіційною. Державні органи, визначені відповідно до нормативно-правового акта, який регламентує функціонування державної інформаційної системи, зобов'язані забезпечити достовірність і актуальність інформації, що міститься в даній інформаційній системі, доступ до зазначеної інформації у випадках i в порядку, передбачених законодавством, а також захист зазначеної інформації від неправомірних доступу, знищення, модифікування, блокування, копіювання, надання, поширення та інших неправомірних дій.

Таким чином, держава за допомогою своїх нормативно-правових актів, використовуючи адміністративно-правовий метод регулювання, визначає принципи і режими використання інформації державними органами, як суб'єктами публічного права, в тому числі органами поліції.

3 огляду на те, що аналітична діяльність має на увазі також збір, зберігання і обробку персональних даних, у застосуванні вищевказаних принципів до інформаційно-аналітичної діяльності необхідно враховувати імперативні норми відповідного законодавства. Хоча відповідне законодавство не містить положень, які безпосередньо б виокремлювали і широко тлумачили принци обробки персональних даних.

Однак ці принципи є фундаментальними засадами правового регулювання у сфері персональних даних, а їх правильне розуміння - необхідна умова запровадження якісних та ефективних національних правових механізмів захисту персональних даних. Тому для з'ясування глибинного змісту принципів обробки персональних даних необхідно звертатися до першоджерел правового регулювання у цій сфері, тобто до європейських правових стандартів захисту персональних даних - відповідних правових актів Ради Європи, Європейського Союзу та рішень європейських судів.

Так, у наукових джерелах виділяють такі принципи обробки персональних даних:

- законність обробки;

- конкретизація мети;

- відкритість і прозорість обробки;

- якість даних, що має включати: відповідність даних меті обробки; точність даних та вчасне оновлення даних; достовірність даних; обмеження періоду зберігання даних; захищеність даних [9].

Права і свободи людини і громадянина не можуть бути обмежені з мотивів, пов'язаних 3 використанням різних способів обробки персональних даних або позначення приналежності персональних даних, що містяться в державних або інших інформаційних системах персональних даних, конкретного суб'єкта персональних даних.

Не допускається використання таких, що ображають почуття громадян, або таких, що принижують людську гідність, способів позначення приналежності персональних даних, що містяться в інформаційних системах персональних даних, конкретного суб'єкта персональних даних.

Вищевикладене твердження теж є принципом інформаційно-аналітичної діяльності органів поліції, що відповідає загальному принципу адміністративного права - пріоритету особистості та її інтересів.

Законодавство визначає особливості обробки персональних даних в інформаційних системах персональних даних і накладає на них відповідні обмеження. Законодавство зобов'язує державні органи забезпечувати доступність, безперервність і захист інформаційних систем, оскільки без цього неможливий їхній розвиток, безперешкодне використання їх з боку громадян та юридичних осіб. Чинне законодавство гарантує права власників інформаційних технологій, інформаційних ресурсів, систем, які, у свою чергу, забезпечуються діяльністю відповідних органів виконавчої влади.

Можливо також виділити сукупність спеціальних принципів інформаційно-аналітичного забезпечення діяльності органів Національної поліції України, які виступають основою для організації аналітичної роботи, до них належать такі.

1. Цілеспрямованість інформаційноаналітичного забезпечення, що передбачає його орієнтацію на досягнення конкретних цілей та вирішення поставлених завдань певним чином. Фактично даний принцип закладає базовий фундаментальний фактор забезпечення результативності управлінської діяльності. 
2. Актуальність, оскільки інформаційно-аналітична діяльність повинна відповідати потребам практичної діяльності поліції. Порушення цього принципу буде автоматично означати порушення принципів цілеспрямованості. Тому інформаційна та аналітична робота має бути спрямована на вирішення конкретних питань високого ступеня важливості.

3. Активність, оскільки функціонування систем інформаційно-аналітичного забезпечення та представлення результатів аналітичної роботи забезпечується на умовах незалежності від конкретних запитів користувачів і містить елементи прогнозування, що зумовлює принцип активності функціонування систем інформаційно-аналітичного забезпечення.

4. Достовірність даних для аналітичної роботи, що вимагає від інформаційного забезпечення точності кількісних даних відсутність суб'єктивності у використовуваних параметрах, досягнення максимального ступеня об'єктивізації й обгрунтованості наступних висновків, оцінок і пропозицій.

5. Повнота наявної інформації, яка необхідна для вирішення поставлених завдань управління і досягнення намічених цілей.

6. Альтернативність функціонування інформаційно-аналітичного забезпечення, яка передбачає можливості вільно сформулювати різні позиції щодо отриманих результатів на основі наявної інформації. Результати проведених досліджень і аналітичних робіт повинні доводитися до вищого керівництва установ та організацій без спотворень, але з урахуванням категоріального аналізу отриманих висновків 3 використанням систем інформаційно-аналітичного забезпечення.

7. Обгрунтованість результатів за підсумками обробки масивів інформації, яка забезпечується на основі сучасних досягнень науки, ефективних інформаційно-аналітичних технологій, що відповідає критерію достатності принципу обгрунтованості.

8. Системність організації інформаційноаналітичного забезпечення, що спирається на підтримку працездатності та комплексний аналіз питань, які підлягають вирішенню, з урахуванням їх місця, ролі та взаємозв'язків у загальній структурі основної діяльності установи або організації.

9. Своєчасність представлення результатів інформаційно-аналітичної роботи, який вимагає їх передачі в потрібні терміни та в зручній формі для кінцевих користувачів.

10. Ініціативність, яка гарантуе точне визначення i опис питань, формування завдань і пропозицію способів вирішення, в тому числі і тих, що виходять за межі традиційних управлінських уявлень.
11. Обєктивність, що забезпечує відсутність тенденційності, неупереджене ставлення аналітика до дослідження і його результатів.

12. Безперервність і гнучкість, які взаємопов'язані між собою на рівні організації постійно діючого інформаційно-аналітичного моніторингу, що дозволяє, з одного боку, своєчасно виявляти зміни, що відбуваються в поточній ситуації, в проведеному дослідженні або реалізації запланованих заходів, а з іншого боку, швидко адаптувати до цих змін управлінську діяльність без кардинальних модифікацій комплексу застосовуваних методів і використовуваних засобів реалізації аналітичної роботи.

\section{Висновки}

Інформаційно-аналітичне забезпечення у сфері управління спрямовано на підвищення його ефективності, результативності та сприяє цільової орієнтації на підвищення рівня організації життєдіяльності суспільства. Принципи інформаційно-аналітичного забезпечення закладають основу методології аналітичних досліджень у рамках управлінських підходів до організації та проведення заходів у конкретних сферах державного і муніципального управління.

Принципи інформаційно-аналітичного забезпечення діяльності органів Національної поліції України можливо класифікувати на види: загальноправові, галузеві та спеціальні. До першої групи входять сукупність загальних принципів, що притаманні усій системі публічного управління. До другої групи - сукупність принципів, які випливають зі змісту галузевих нормативно-правових актів, що визначають порядок роботи з інформацією та засади аналітичної роботи. До третьої групі належать спеціальні принципи, що обумовлюють порядок організації інформаційно-аналітичного забезпечення діяльності органів поліції.

\section{Список використаних джерел:}

1. Павлов Д.М. Мета, завдання та принципи адміністративно-правового регулювання природно-техногенної безпеки та цивільного захист. Митна справа. 2015. № 4(2). С. 267-274.

2. Драмаренко К.Б. Принципи адміністративно-правового регулювання діяльності політичних партій в Україні. Науковий вісник Ужгородського Наиіонального університету. Серія «Право». 2016. № 41. Том. 4. С. 182-186.

3. Шинкарук А.І. Принципи адміністративноправового регулювання діяльності нотаріусів у сфері державної реєстрації. Актуальні проблеми вітчизняної юриспрудениії. 2017. № 6. Том. 4. C. $372-375$.

4. Принципи адміністративного права. Науково-дослідний інститут публічного права: 
веб-сайт. 2015. URL: http://sipl.com.ua/?page_ $\mathrm{id}=1517$ (дата звернення: 12.08.2020).

5. Конституція України від 28 червня 1996 року. Відомості Верховної Ради. 1996. № 30. Ст. 141.

6. Сердюк $€$. В. Принципи адміністративноправового забезпечення виборчих прав громадян України. Інформачія і право. 2014. № 2. С. 72-78.

7. Про інформацію : Закон України від 2 жовтня 1992 року № 2657-XII. URL: https://zakon.rada.gov.ua/laws/show/2657-12 (дата звернення: 12.08.2020).

8. Про доступ до публічної інформації : Закон України від 13 січня 2011 року № 2939-VI. URL: https://zakon.rada.gov.ua/laws/show/2939-17 (дата звернення: 12.08.2020).

9. Ключові принципи обробки ПД. Захист персональних даних: правове регулювання. URL: http://zpd.inf.ua/page14.html (дата звернення: 12.08.2020).

Yana Kovalchuk. Principles of information and analytical support of the activities of agencies of the National Police of Ukraine

The purpose of the article is to analyze the existing system of principles of information and analytical support of the National Police of Ukraine, as well as to formulate proposals for improving certain areas in this area. The article considers the problematic issues of defining the System of principles of information and analytical support of the National Police of Ukraine. The general principles of administrative laze enshrined in the Constitution of Ukraine are considered, concretized and developed in legislative and other regulations. In addition, the study of special industry principles are interrelated with the principles of public administration, which in the rules of administrative law appear in a modified form, taking the form of specific mandatory requirements. The rights and freedoms of man and citizen may not be restricted for reasons related to the use of different methods of personal data processing or indication of personal data contained in state or other personal data information systems of a particular personal data subject. It is not allowed to use offensive feelings of citizens or degrading methods of marking the affiliation of personal data contained in the information systems of personal data, a particular subject of personal data. A group of special principles of information and analytical support of the National Police of Ukraine, which are the basis for the organization of analytical work. It is determined that the principles of information and analytical support of the National Police of Ukraine can be classified by types into: general, sectoral and special. The first group includes a set of general principles that characterize the entire system of public administration. To the second - a set of principles that follow from the content of sectoral regulations that determine the procedure for working with information and the principles of analytical work. To the third - special principles that determine the order of organization of information and analytical support of the police.

Key words: analytical support, police bodies, system of principles, legal regulation, public administration. 